\title{
Efficient biomass value chains for heat production from energy crops in Ukraine
}

\author{
Oleksandra V. Tryboi \\ Institute of Engineering Thermophysics \\ of NAS of Ukraine, \\ Zheliabova St. $2 a$, \\ 03680 Kyiv, Ukraine \\ Email: tryboiov@nas.gov.ua
}

\begin{abstract}
The purpose of the paper is to identify the most energy efficient value chains using solid biomass of specially grown energy crops and the most significant parameters affecting their energy efficiency and environmental sustainability. The methodology of Life Cycle Assessment (LCA) was used to determine the energy efficiency of value chains of heat production from energy crops. According to the methodology, the scope of the product system includes the raw material cycle of growing energy crops and the subsystem of transformation with production of thermal energy. Cumulative energy demand and energy yield coefficient were chosen as energy efficiency indicators. The product system was compared with a similar one using natural gas. The non-renewable energy yield coefficient was used to define how many times the energy output was bigger than the input of non-renewable energy. Assessment was conducted for two energy crops: Miscanthus as a typical representative of specially grown grassy energy crops and willow as a typical representative of specially grown woody energy crops. The growing of energy crops in Ukraine for the subsequent production of biofuel in the form of chips and their combustion in biofuel boilers are energetically effective with a maximum transportation distance of $400 \mathrm{~km}$ for Miscanthus chips and $180 \mathrm{~km}$ for willow chips.
\end{abstract}

Keywords: energy crops, Miscanthus, willow, LCA, energy efficiency, GHG, Cumulative Energy Demand, Energy Yield Coefficient, bioenergy heat

\section{INTRODUCTION}

Ukraine is now on the track of obtaining energy independence, searching for energy alternatives to fossil coal and natural gas. Despite a significant boost that is recently observed in the development of wind and solar energy sectors in Ukraine, the most reliable renewable energy source (RES) is still biomass. Biomass is now a major RES used in Ukraine in terms of prima- ry energy supply, amounting to $81.3 \%$ from all RES in 2015 [1] with $5.22 \mathrm{E}+8 \mathrm{MJ}$ of produced electricity and $6.42 \mathrm{E}+10 \mathrm{MJ}$ of produced heat [2]. Biomass potential in Ukraine includes various sources, but according to the data of Bioenergy Association of Ukraine the major biomass resource potential belongs to energy crops and amounts to $2.75 \mathrm{E}+11 \mathrm{MJ}$ [3], considering the growing of energy crops on the area of 1.5 million ha. According to RE Directive [4], growing 
of energy crops must not result in land use change influencing the food/feed crops cultivation. The potential lands that are acceptable for growing energy crops are underutilized lands that are unsuitable for agriculture. On the other hand, underutilized lands can influence energy crops yields negatively that discourages potential investors, including agrarians, to be involved into this business. The paper presents the results of energy efficiency assessment of the biomass-to-energy value chains using solid biomass of specially grown energy crops in Ukraine.

\section{LIFE CYCLE METHODOLOGY}

\section{Goal and scope definition}

The goal of this study is to quantify greenhouse gas emissions (GHG), cumulative energy demand (CED) [5] and cumulative energy demand of non-renewable sources $\left(C E D_{N R}\right)$ [5] of two value chains of complete life cycles of heat production from Miscanthus and willow, and to assess the influence of most critical parameters on the energy yield coefficient ( $E Y C$ and $E Y C_{N R}$ ) [5] of each value chain, as well as to compare them with each other and with fossil natural gas ones.

The functional unit of the system is MJ of heat produced in the $500 \mathrm{~kW}$ biomass boiler that combusts chips produced at the harvest of Miscanthus and willow cultivated at plantations over the assumed life cycle of 20 years.

The life cycle boundaries for the assessment of the energy-crops-to-heat value chain are shown in Fig. 1. Energy crops analysed in the assessment are Miscanthus (M) and willow (W). The scope includes the feedstock sub-cycle with inputs from soil preparation, planting, caring for plants, biomass harvesting, wood chips transport and storage, and the processing sub-cycle that includes boiler manufacture and dismantling and heat production during 20 years, but it does not include heat transport and heat consumption by final consumers.

\section{Life cycle inventory}

Data on inputs for all the processes identified within the life cycle were collected. Data on technological operations and machinery used in the feedstock cycle are based on consultations with operating producers of energy crops (farmers (M), companies (W)) (Table 1). The input to the system at such stages as growing, harvest with shredding, transporting and storage, and disposal of products of combustion contains consumption of diesel, pesticides and fertilizers.

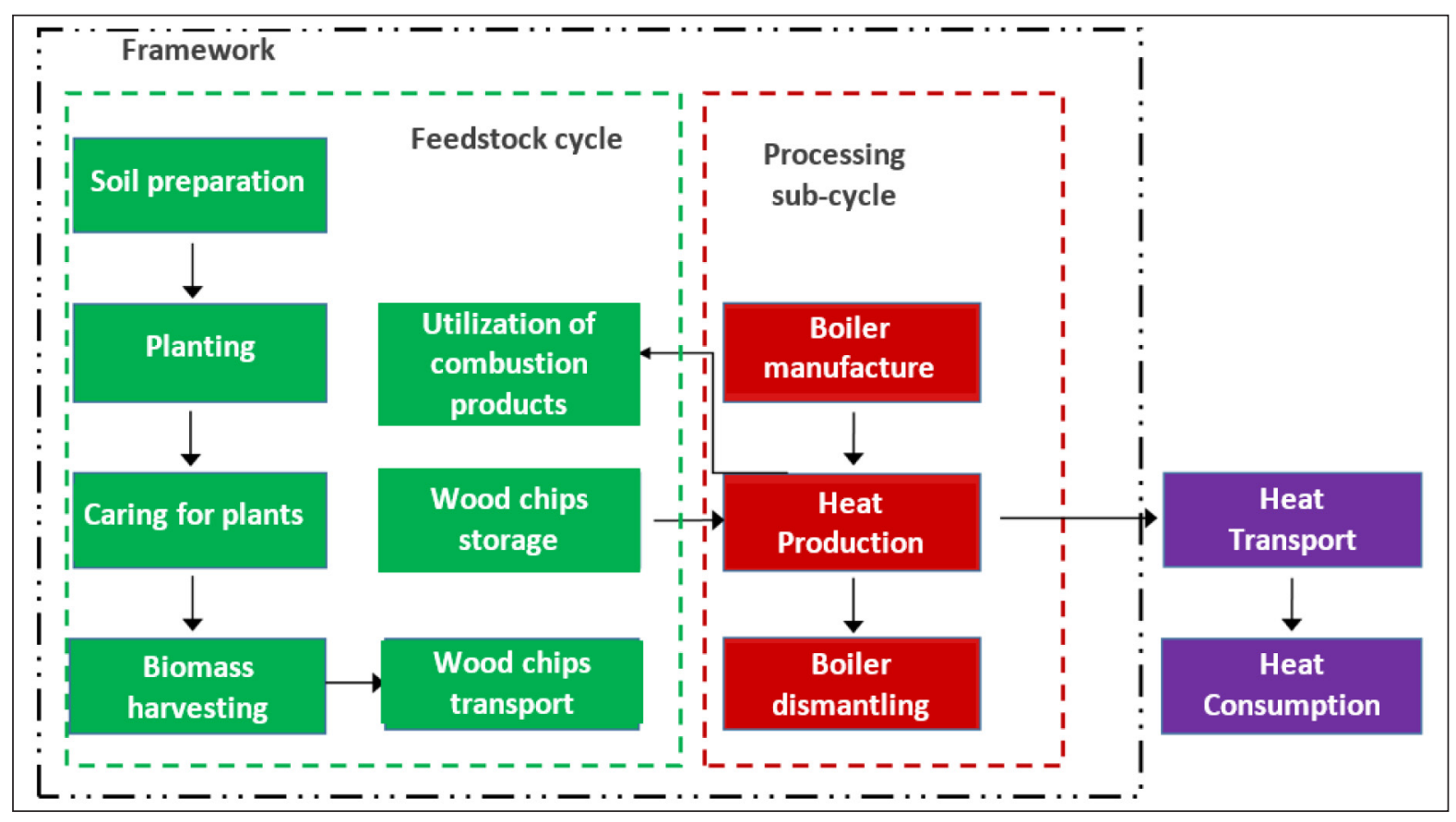

Fig. 1. Life cycle boundaries of the energy-crops-to-heat value chain 
Table 1. Technological operations applied during 20-year life cycle with frequency

\begin{tabular}{|c|c|c|c|}
\hline \multirow{2}{*}{ Technological operations } & \multirow{2}{*}{ Frequency } & \multicolumn{2}{|c|}{ Machinery } \\
\hline & & Miscanthus (M) & Willow (W) \\
\hline Disking up to $12 \mathrm{~cm}$ depth & 1 & \multicolumn{2}{|c|}{ HTZ-242K + Harrow BDVP-5,5 } \\
\hline Ploughing up to $30 \mathrm{~cm}$ depth & 1 & \multicolumn{2}{|c|}{ John Deere 8360R + KUHN-6 } \\
\hline Pre-plant cultivation & 1 & \multicolumn{2}{|c|}{ HTZ-242K + KPS-8 } \\
\hline Pre-emergence harrowing & 2 & $\begin{array}{c}\text { MTZ-892 + Harrow } \\
\text { BPN-12 }\end{array}$ & $\mathrm{X}$ \\
\hline Inter-row cultivation & 1 & \multirow[t]{2}{*}{$x$} & $\begin{array}{l}\text { HTZ-242 + Folding power } \\
\text { harrow Celli Ranger } 400\end{array}$ \\
\hline Inter-row disking & $1(\mathrm{M}) ; 2(\mathrm{~W})$ & & $\begin{array}{l}\text { John Deere } 8360 R+\text { Disc } \\
\text { plough-harrow LSD-3,7 }\end{array}$ \\
\hline Herbicide preparation and spraying & $4(\mathrm{M}), 3(\mathrm{~W})$ & \multicolumn{2}{|c|}{ MTZ-892 + Sprayer HARDI RANGER } \\
\hline Fertilizer spreading & 1 & \multicolumn{2}{|c|}{ HTZ-242K + RUM-8 } \\
\hline Planting & 1 & MTZ-892 + KSN-L-202 & $\begin{array}{l}\text { John Deere } 8360 R+ \\
\text { Egedal } 4 \text { row }\end{array}$ \\
\hline Harvesting & $20(\mathrm{M}), 7(\mathrm{~W})$ & Claas Jaguar & $\begin{array}{c}\text { Claas Jaguar + HSAB's SRC } \\
\text { Chipping Head }\end{array}$ \\
\hline Removal & 1 & $\begin{array}{l}\text { HTZ-242K + Harrow } \\
\text { BDVP } 5.5\end{array}$ & $\begin{array}{l}\text { John Deere } 6930+\text { Multi- } \\
\text { forst }\end{array}$ \\
\hline Transport of rhizomes/seedlings & 1 & $\begin{array}{l}\text { John Deere } 6930+ \\
\text { Tractor-trailer 2PTS-6 }\end{array}$ & $\begin{array}{c}\text { Transport of rhizomes/ } \\
\text { seedlings }\end{array}$ \\
\hline Transport of water for herbicide & $4(\mathrm{M}), 3(\mathrm{~W})$ & $\begin{array}{l}\text { John Deere } 6930+ \\
\text { Tanker RZS-6 }\end{array}$ & $\begin{array}{c}\text { Transport of water for } \\
\text { herbicide }\end{array}$ \\
\hline Transport of fertilizer & $1(\mathrm{M}), 7(\mathrm{~W})$ & $\begin{array}{l}\text { John Deere } 6930+ \\
\text { Tractor-trailer 2PTS-6 }\end{array}$ & Transport of fertilizer \\
\hline Transport of chips to local storage & $20(\mathrm{M}), 7(\mathrm{~W})$ & $\begin{array}{c}\text { John Deere } 6930 \\
\text { (HTZ-242K, MTZ-892) + } \\
\text { Tractor-trailer 2PTS-6 }\end{array}$ & $\begin{array}{c}\text { Transport of chips to local } \\
\text { storage }\end{array}$ \\
\hline $\begin{array}{c}\text { Transport of chips to central stor- } \\
\text { age of boiler-house }\end{array}$ & $35(\mathrm{M}), 29(\mathrm{~W})$ & $\begin{array}{l}\text { MAZ-6501C9-8525-000 } \\
\text { with trailer }\end{array}$ & $\begin{array}{l}\text { Transport of chips to cen- } \\
\text { tral storage of boiler-house }\end{array}$ \\
\hline Loading/unloading operations & $70(\mathrm{M}), 58(\mathrm{~W})$ & Front loade & MAN BME-1560 \\
\hline
\end{tabular}

Diesel consumption was calculated according to Equation (1). For diesel, pesticides and fertilizers consumption and primary energy input for their production are also considered [6]. For all stages that use machinery and equipment, the consumption of primary energy for their production is considered in proportion to time of their use in the process.

$$
Q_{\text {hourly }}=\frac{N_{c} * q_{0} * k_{e . l .}}{100_{0}}
$$

where $Q_{\text {hourly }}$ is hourly fuel consumption, $N_{c}$ is engine power, $q_{0}$ is specific fuel consumption, and $k_{e . l}$ is the coefficient that takes into account the engine load [7].

Consumption amounts of pesticides and fertilizers were provided by operating producers of energy crops (Tables 2 and 3 ).

For a heat boiler, non-renewable energy used for construction and dismantling is considered, as well as electricity consumption, repairs and maintenance. In addition, the primary energy used for the production of planting material and for the production of fertilizers, herbicides, and insecticides (for a cycle of growing willow) in proportion to their required volume is considered. For all transport operations, such as 
Table 2. Pesticides applied for $M$ and $W$ plantations

\begin{tabular}{|c|c|c|c|}
\hline \multirow{2}{*}{ Pesticide type } & \multirow{2}{*}{ Active ingredient } & \multicolumn{2}{|c|}{ Norm of application, l/ha } \\
\hline & & Miscanthus (M) & Willow (W) \\
\hline Herbicide & Glyphosate $450 \mathrm{~g} / \mathrm{l}$ & \multicolumn{2}{|c|}{2.4} \\
\hline Herbicide & Pendimethalin $330 \mathrm{~g} / \mathrm{l}$ & $x$ & 3 \\
\hline Herbicide & $\begin{array}{l}\text { 2,4-D acid (complex 2-ethylhexyl ether) + to florasula, } \\
\qquad 300 \mathrm{~g} / \mathrm{l}+6.25 \mathrm{~g} / \mathrm{l}\end{array}$ & 0.5 & $x$ \\
\hline Insecticide & Imidacloprid $600 \mathrm{~g} / \mathrm{l}$ & $x$ & 0.5 \\
\hline
\end{tabular}

Table 3. Fertilizers applied for $M$ and $W$ plantations

\begin{tabular}{c|c|c|c}
\multirow{2}{*}{ Fertilizer name } & \multirow{2}{*}{ Active ingredient } & \multicolumn{2}{c}{ Norm of application, $\mathbf{k g} / \mathbf{h a}$} \\
\cline { 3 - 4 } & & Miscanthus (M) & Willow (W) \\
\hline Di-amonium-phosphate & $9 \% \mathrm{~N}, 30 \% \mathrm{P}$ & $\mathrm{X}$ & $\mathrm{X}$ \\
\hline NPK & $16 \% \mathrm{~N}, 16 \% \mathrm{P}, 16 \% \mathrm{~K}$ & 375 & 682 \\
\hline Potassium-Magnesium & $\mathrm{K} \geq 44 \ldots 48 \%, \mathrm{Mg}-4 \ldots 7 \%, \mathrm{~S} \leq 3 \%$ & $\mathrm{X}$ & 188 \\
\hline UAN-32 & $\mathrm{Na}+\mathrm{Cu}+\mathrm{Zn}+\mathrm{Ca} \leq 20 \%$ & $\mathrm{X}$ & $\mathrm{X}$ \\
\hline Urea & $32 \% \mathrm{~N}$ & 100 & $\mathrm{~N}$ \\
\hline
\end{tabular}

transport of water for herbicides, transport of fertilizers, planting material (by tractors with trailers) and harvested chips (by tractors with trailers to a local storage and by trucks with trailers to the central storage/boiler house), the use of diesel is considered. Transportation distance of $5 \mathrm{~km}$ to the local storage is considered for these processes, except for transport of chips to the central storage/boiler house. In the latter case, transportation distance is a variable, showing the impact on energy efficiency and GHG emissions reduction of the assessed value chains.

\section{Energy efficiency and environmental sustainability indicators}

Cumulative energy demand of non-renewable sources was calculated for the assessed life cycles, where heat energy is a product received in a biofuel boiler according to the system of Equations (2). The biofuel for this boiler is the chips of energy crops, such as Miscanthus or willow. Chips, as a biofuel, are obtained during harvesting with the shredding of the energy crop from the plantations where this crop was grown (feedstock cycle).

$$
\begin{aligned}
& C E D_{N R}=E_{f d s k}+E_{p r o s} ; \\
& E_{f d s k}=B \cdot \sum_{i=0}^{n} E_{i} ; \\
& E_{p r o s}=E_{m}+E_{e l}+E_{b} / n ; \\
& C E P=\sum W_{i} \cdot \tau_{i} ; \\
& E Y C_{N R}=\frac{C E P}{C E D_{N R}} ; \\
& E Y C_{N R}>5,
\end{aligned}
$$

where $E_{f d s k}$ is primary energy spent in the feedstock cycle for harvesting with shredding of energy crops from the field, transportation, as well as loading/unloading operations and storage of biofuels in GJ/a; $E_{m}$ is primary energy consumption for the repair and maintenance of boiler equipment; $E_{e l}$ is own electricity consumption of the boiler; $E_{b}$ is primary energy consumption at the stage of construction and dismantling of the plant; $n$ is a period of boiler lifetime, and CEP is production of heat energy by the boiler plant, GJ/a.

Yearly yields of Miscanthus and willow differ, as Miscanthus is harvested annually, and willow every three years. Yields in the first 1-2 years are also less for these crops, so mean yields were assumed in the assessment. Mean yields of Miscanthus and 
willow are calculated according to Equation (3) and Equation (4), correspondingly:

$$
\begin{aligned}
& \text { Mean yield Miscanthus }\left[\mathrm{tha}^{-1} \mathrm{yr}^{-1}\right]= \\
& \frac{\left(1 . \text { yield }+2 . \text { yield }+3 . \text { yield }^{*} 18\right)}{2_{0}}
\end{aligned}
$$

Mean yield willow $\left[\mathrm{tha}^{-1} \mathrm{yr}^{-1}\right]=$

$$
\frac{(1 . \text { yield } * 2+2 \text {.yield } * 5)}{2_{0}} \text {. }
$$

GHG emissions reduction at heat production from biomass compared to gas is calculated according to Equation (5), where specific GHG emissions from heat production from biomass are calculated according to Equation (6):

$$
\begin{aligned}
& E C_{h}=\varepsilon / \eta_{h},\left[\mathrm{gCO}_{2-\mathrm{eq} \cdot /}, M J_{\text {heat }}\right], \\
& \Delta \varepsilon=\left(E C F_{h}-E C_{h}\right) / E C F_{h},[\%],
\end{aligned}
$$

where $E C F_{h}$ are specific GHG emissions in the production of heat from natural gas, $80 \mathrm{gCO}_{2 \text {-eq. }}$ ! $M J_{\text {heat }}[8] ; \varepsilon$ are GHG emissions from the production of biomass before its conversion into heat, and $\mathrm{gCO}_{2 \text {-eq. }} / t_{\text {biomass }}, \eta_{h}$ is the efficiency of heat production, calculated as the ratio of annual heat production to annual fuel consumption, $M J_{\text {heat }}$ ' $t_{\text {biomass }}$.

\section{RESULTS}

For installations on renewable energy sources, indicators that consider only consumption of non-renewable energy in the input of technological processes and operations of the value chain are used $\left(C E D_{N R}, E Y C_{N R}\right)$. The non-renewable energy yield coefficient means how many times the energy production is bigger than the input of non-renewable energy. An acceptable value for renewable energy installations is to receive twice as much energy output as was spent of non-renewable energy; however, the recommended value is assumed in the work, which means the output of 5 times more energy than was spent of non-renewable energy [5].

Cumulative energy demand of non-renewable sources was calculated for the assessed life cycles, where heat energy is a product received in a biofuel boiler. The biofuel for this boiler is the chips of energy crops, such as Miscanthus or willow. Chips, as a biofuel, are obtained during harvesting with the shredding of the energy crop from the plantations where this crop was grown (feedstock cycle) (Table 4 ).

As a result of energy efficiency calculations for a biofuel boiler of $500 \mathrm{~kW}$ of installed heat capacity, the following results were obtained. For value chains "Miscanthus-to-heat" (Table 5) and "willow-to-heat" (Table 6), the indicators of cumulated energy demand and energy yield coefficients remained within the recommended values $\left(E Y C_{N R}>5\right.$. $)$ for transport distances of biofuels up to $400 \mathrm{~km}$ and up to $180 \mathrm{~km}$, respectively.

As an environmental sustainability indicator, a reduction of GHG emissions was used. The ac-

\begin{tabular}{|c|c|c|c|c|c|}
\hline & \multirow{2}{*}{ Components } & \multicolumn{2}{|c|}{$\begin{array}{c}\text { Miscanthus, } \\
\text { life cycle } 20 \text { years }\end{array}$} & \multicolumn{2}{|c|}{$\begin{array}{c}\text { Willow, } \\
\text { life cycle } 20 \text { years }\end{array}$} \\
\hline & & GJ/year & GJ/ha/year & GJ/year & GJ/ha/year \\
\hline 1. & Soil tillage operations & 4.3 & 0.13 & 6.54 & 0.16 \\
\hline 2. & Planting & 6.9 & 0.21 & 10.03 & 0.24 \\
\hline 3. & Fertilizer spreading & 37.98 & 1.15 & 73.39 & 1.79 \\
\hline 4. & Weeding & 1.33 & 0.04 & 2.87 & 0.07 \\
\hline 5. & Harvest with shredding & 50.15 & 1.52 & 32.82 & 0.80 \\
\hline \multirow[t]{2}{*}{6.} & $\begin{array}{c}\text { Transport (fertilizer, water for herbicides, } \\
\text { planting material) for } 2 \mathrm{~km}\end{array}$ & 37.88 & 1.15 & 13.86 & 0.34 \\
\hline & Total & 138.54 & 4.20 & 139.51 & 3.40 \\
\hline
\end{tabular}
ceptable level of GHG emissions reduction was chosen at a level of $60 \%$ for the whole life cycle from cradle-to-heat, compared to traditional heat

Table 4. Cumulative energy demand for growing and harvesting Miscanthus and willow (CED $\left.D_{N R}\right)$ 
Table 5. Energy efficiency of "Miscanthus-to-heat" value chain, $500 \mathrm{~kW}$

\begin{tabular}{|c|c|c|c|c|c|}
\hline Components & \multicolumn{5}{|c|}{ GJ/year } \\
\hline 1. Fuel supply (Miscanthus chips) for boiler & \multicolumn{5}{|c|}{$463.6 \mathrm{t} /$ year } \\
\hline 2. Miscanthus cultivation (on area $33 \mathrm{ha}$ ) & \multicolumn{5}{|c|}{88.39} \\
\hline 3. Harvest with shredding & \multicolumn{5}{|c|}{50.15} \\
\hline $\begin{array}{l}\text { 4. Loading, unloading, storing and storage of chips of } \\
\qquad \text { Miscanthus }\end{array}$ & \multicolumn{5}{|c|}{31.54} \\
\hline $\begin{array}{l}\text { 5. Boiler operation (electricity consumption, repairs, } \\
\text { maintenance) }\end{array}$ & \multicolumn{5}{|c|}{126.2} \\
\hline $\begin{array}{l}\text { 6. Construction of the boiler (manufacturing equip- } \\
\text { ment, construction and installation work) }\end{array}$ & \multicolumn{5}{|c|}{30} \\
\hline $\begin{array}{l}\text { 7. Dismantling, utilization of boiler installation } \\
\text { equipment }\end{array}$ & \multicolumn{5}{|c|}{3.8} \\
\hline \multirow{2}{*}{$\begin{array}{l}\text { 8. Transportation of Miscanthus chips } \\
\text { (field-central storage-boiler house) }\end{array}$} & $0 \mathrm{~km}$ & $50 \mathrm{~km}$ & 100 km & $200 \mathrm{~km}$ & $400 \mathrm{~km}$ \\
\hline & 0 & 80.25 & 160.5 & 321.0 & 642 \\
\hline CED: Energy input (sum of items 1-8) & 6663 & 6743 & 6823 & 6984 & 7305 \\
\hline EYC: Energy output / Energy input & 0.77 & 0.76 & 0.75 & 0.73 & 0.70 \\
\hline$C E D_{N R}:$ Energy input (sum of items 2-8) & 330 & 410 & 491 & 651 & 972 \\
\hline$E Y C_{N R}:$ Energy output / Energy input & 15.49 & 12.46 & 10.42 & 7.85 & 5.26 \\
\hline
\end{tabular}

Table 6. Energy efficiency of "willow-to-heat" value chain, $500 \mathrm{~kW}$

\begin{tabular}{|c|c|c|c|c|c|}
\hline Components & \multicolumn{5}{|c|}{ GJ/year } \\
\hline 1. Fuel supply (willow chips) for boiler & \multicolumn{5}{|c|}{755.0 year } \\
\hline 2. Willow cultivation (on area $41 \mathrm{ha}$ ) & \multicolumn{5}{|c|}{106.69} \\
\hline 3. Harvest with shredding & \multicolumn{5}{|c|}{32.82} \\
\hline 4. Loading, unloading, storing and storage of willow chips & \multicolumn{5}{|c|}{50.65} \\
\hline $\begin{array}{l}\text { 5. Boiler operation (electricity consumption, repairs, } \\
\text { maintenance) }\end{array}$ & \multicolumn{5}{|c|}{125.8} \\
\hline $\begin{array}{l}\text { 6. Construction of the boiler (manufacturing equipment, } \\
\text { construction and installation work) }\end{array}$ & \multicolumn{5}{|c|}{17.7} \\
\hline 7. Dismantling, utilization of boiler installation equipment & \multicolumn{5}{|c|}{2.2} \\
\hline \multirow{2}{*}{$\begin{array}{l}\text { 8. Transportation of willow chips (field-central storage- } \\
\text { boiler house) }\end{array}$} & $0 \mathrm{~km}$ & $50 \mathrm{~km}$ & 100 km & 180 km & $400 \mathrm{~km}$ \\
\hline & 0 & 189.35 & 378.7 & 681.65 & 1514.78 \\
\hline CED: Energy input (sum of items 1-8) & 6668 & 6858 & 7047 & 7350 & 8183 \\
\hline EYC: Energy output /Energy input & 0.77 & 0.75 & 0.73 & 0.7 & 0.62 \\
\hline$C E D_{N R}:$ Energy input (sum of items 2-8) & 336 & 525 & 715 & 1017 & 1851 \\
\hline$E Y C_{N R}:$ Energy output /Energy input & 15.23 & 9.74 & 7.16 & 5.03 & 2.76 \\
\hline
\end{tabular}




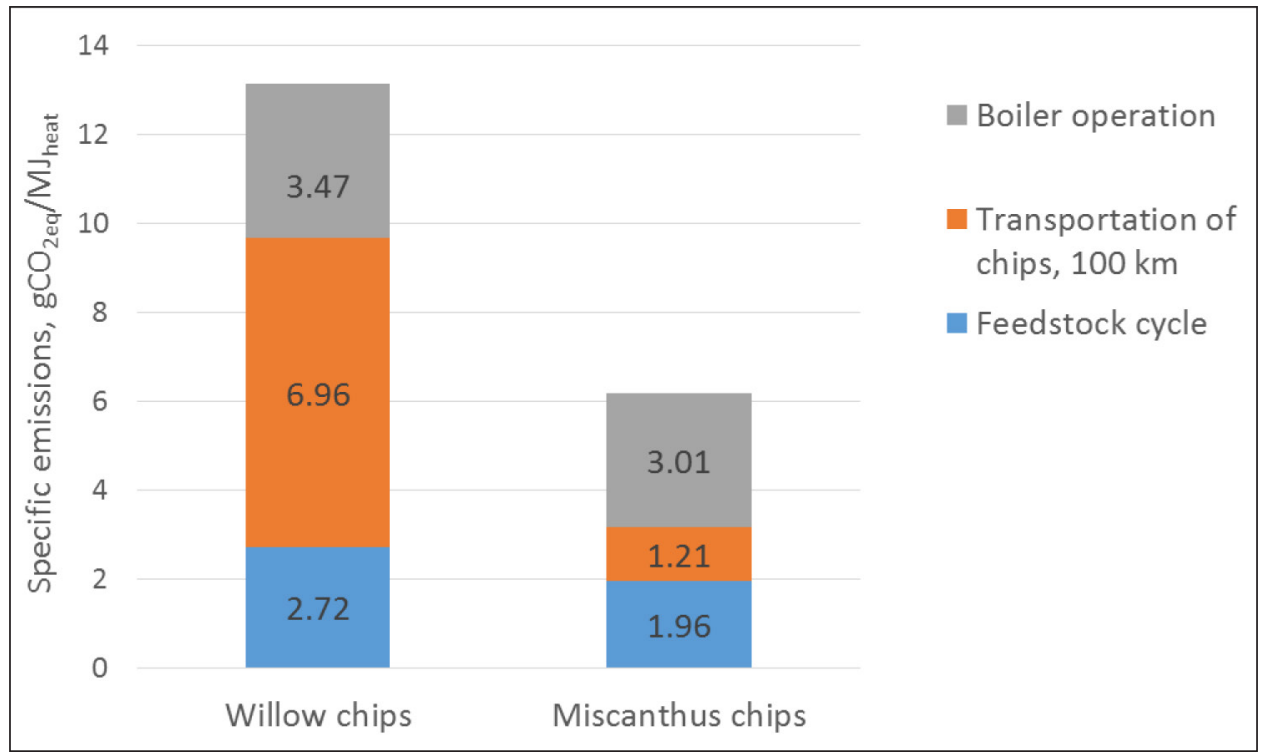

Fig. 2. Specific GHG emissions for "willow-to-heat" and "Miscanthus-to-heat" value chains

production in gas boilers, according to RE Directive 2009/28/EC [4]. Specific GHG emissions reduction for heat production from energy crops at a transportation distance of $100 \mathrm{~km}$ are shown in Fig. 2, and the influence of transportation distance of willow and Miscanthus chips for heat production in a biomass boiler at GHG emissions reduction compared to traditional heat production in a gas boiler is shown in Table 7 .

\section{DISCUSSION}

Biomass is widely used for energy in many countries and most likely its share will remain significant among other renewables in the future. Due to this, there is a need to define the most viable bioenergy systems that contribute to GHG emissions reduction by reducing fossil fuels consumption in similar energy pathways. There is a variety of conversion processes for biomass-to-energy value chains and approaches to define bound- aries, functional unit and reference product of the system, as well as methodological assumptions that make results of life cycle assessments more specific and complicate their comparison with each other. Available researches that use the life cycle approach for energy crops value chains investigate the feedstock cycle from planting to harvest $[9,10]$ or biofuels production $[11,12]$. Analysed papers that assess energy conversion pathways use specific LCA tools usually with a variety of impact categories and receive results as normalized values that show the calculated impact as a proportion of the emissions of an average European citizen $[12,13]$. Such approach is not applicable for Ukrainian conditions, as there is lack of required local input data available (for example, emissions of an average Ukrainian citizen). For this reason, LCA based on GHG and energy balance was applied in research of forest and agro biomass for heat energy pathways conducted under Ukrainian conditions [14]. The results

Table 7. GHG emissions reduction compared to heat production from natural gas in a $500 \mathrm{~kW}$ heat boiler, $\%$

\begin{tabular}{c|c|c|c|c|c|c|c|c|c|c}
\hline \multirow{2}{*}{ Energy crop } & \multicolumn{10}{c}{ Transportation distance, $\mathbf{k m}$} \\
\cline { 2 - 12 } & $\mathbf{0}$ & $\mathbf{5 0}$ & $\mathbf{1 0 0}$ & $\mathbf{1 5 0}$ & $\mathbf{2 0 0}$ & $\mathbf{3 0 0}$ & $\mathbf{4 0 0}$ & $\mathbf{5 0 0}$ & $\mathbf{6 0 0}$ & $\mathbf{1 7 0 0}$ \\
\hline Willow & 92.63 & 88.48 & 84.34 & 80.19 & 76.05 & 67.76 & $\mathbf{5 9 . 4 7}$ & 51.18 & $\mathbf{4 2 . 8 8}$ & - \\
\hline Miscanthus & 92.44 & 91.51 & 90.59 & 89.66 & 88.74 & 86.89 & 85.04 & 83.19 & 81.34 & $\mathbf{6 1 . 0 1}$ \\
\hline
\end{tabular}


of LCA for value chains of wood chips and straw bales combustion in a $350 \mathrm{~kW}$ boiler show the energy efficiency of these pathways for transport distance of up to $150 \mathrm{~km}$ for wood chips and up to $200 \mathrm{~km}$ for straw bales $\left(E Y C_{N R}>5\right)$. Results of the present research show that the feedstock cycle for willow chips to the heat value chain is almost similar to the feedstock cycle of forest wood chips in terms of non-renewable energy consumption. The Miscanthus-chips-to-heat value chain shows even a better energy efficiency than the straw-toheat value chain $\left(E Y C_{N R}>5\right.$ for $400 \mathrm{~km}$ for Miscanthus compared to $200 \mathrm{~km}$ for straw) that can be explained by a higher net calorific value of Miscanthus compared to straw, as well as higher yield per ha. GHG emissions reduction of energy crops to heat pathways is less compared to that analysed in [14] due to application of fertilizers and pesticides that have high emission factors, but still performs a 60\% GHG emission reduction at transportation distances of $390 \mathrm{~km}(\mathrm{~W})$ and $1700 \mathrm{~km}(\mathrm{M})$.

\section{CONCLUSIONS}

The growing of energy crops in Ukraine for the subsequent production of biofuel in the form of chips and their combustion in biofuel boilers are energy effective with a maximum transportation distance of $400 \mathrm{~km}$ for Miscanthus chips and $180 \mathrm{~km}$ for willow chips and environmentally sustainable at transportation of $390 \mathrm{~km}$ and $1700 \mathrm{~km}$ for willow and Miscanthus chips, correspondingly.

Received 1 April 2018 Accepted 15 May 2018

\section{References}

1. Energy Balance of Ukraine 2015. Express-issue of the State Statistics Service of Ukraine. Official issue: http://www.ukrstat.gov.ua/express/ expr2016/12/245w.zip

2. Report on Promotion of the Use of Energy from Renewable Sources and Consumption in Ukraine in 2014-2015. Official issue: https://www. energy-community.org/dam/jcr:386259293c80-4a80-878e-0b3791e143e2/UA_RE_progress_2016.pdf
3. Geletukha G. Development and prospects of bioenergy in Ukraine. Prospects of biofuel market development. International Conference "BIOMASS FOR ENERGY 2017”. http://uabio.org/en/ uabio-news/3378-uabioconf-2017-geletukhaprospects-of-biofuels-market-in-ukraine

4. RE Directive 2009/28/EC. http://eur-lex.europa. eu/legal-content/EN/TXT/PDF/?uri=CELEX:32009L0028\&from $=\mathrm{EN}$

5. Nussbaumer T., Oser M. Evaluation of biomass combustion based energy systems by cumulative energy demand and energy yield coefficient. Report for International Energy Agency and Swiss Federal Office of Energy, 2004. http://www.ieabcc.nl/publications/Nussbaumer_IEA_CED_ V11.pdf

6. Pastukhov V. I. Enerhetychna otsinka mekhanizovanykh tekhnolohii roslynnytstva. Metody $i$ rezultaty. Kharkiv: "Ranok-NT", 2003. 100 s. [in Ukrainian].

7. Mazniev Ye. Proektuvannia tekhnolohii ta rozrakhunok vytrat na vyroshchuvannia silskohospodarskykh kultur. Kharkiv: "Maidan”, 2009. 257 s. [in Ukrainian].

8. State of play on the sustainability of solid and gaseous biomass used for electricity, heating and cooling in the EU. Commission staff working document. Brussels, 28.07.2014. SWD (2014) 259 final.

9. Heller M., Keoleian G., Volk T. Life cycle assessment of a willow bioenergy cropping system. Biomass and Bioenergy. 2003. Vol. 25. Iss. 2. P. 147165.

10. Gasol C. M., Gabarrell X., Anton A., Rigola M., Carrasco J., Ciria P., et al. Life cycle assessment of a Brassica carinata bioenergy cropping system in southern Europe. Biomass and Bioenergy. 2007. Vol. 31. Iss. 8. P. 543-555.

11. Blottnitz von H., Curran M. A review of assessments conducted on bio-ethanol as a transportation fuel from a net energy, greenhouse gas, and environmental life cycle perspective. Journal of Cleaner Production. 2007. Vol. 15. Iss. 7. P. 607619.

12. Fantozzi F., Buratti C. Life cycle assessment of biomass chains: Wood pellet from short rotation coppice data measured on a real plant. Biomass and Bioenergy. 2010. Vol. 34. Iss. 12. P. 17961804. 
13. Wagner M., Kiesel A., Hastings A., Iqbal Ya., Lewandovski I. Novel Miscanthus germplasm-based value chains: a life cycle assessment. Frontiers in Plant Science. 2017. Vol. 8. Article 990. P. 1-18.

14. Zheliezna T. A., Drozdova O. I. Kompleksnyj analiz tehnologij proizvodstva jenergii iz tverdoj biomassy v Ukraine. Teploenergetika. 2014. No. 4. P. 16-20.

\section{Oleksandra V. Tryboi}

\section{EFEKTYVIOS BIOMASĖS VERTĖS GRANDINĖS, SKIRTOS ŠILUMOS GAMYBAI IŠ ENERGETINIŲ KULTŪRŲ UKRAINOJE}

\section{Santrauka}

Straipsnio tikslas - pristatyti efektyviausias vertès grandines, naudojant specialiai auginamų energinių augalų kietąją biomasę, ir svarbiausius parametrus, turinčius itakos efektyviam energijos vartojimui ir aplinkos tvarumui. Gyvavimo ciklo įvertinimo metodika buvo naudojama energetinių augalų vertès grandinių energijos efektyvumui, gaminant šilumą, nustatyti. Remiantis metodika, produktų sistema apima energetinių augalų žaliavų auginimo ciklą ir transformacijos posistemę, kurioje gaminama šiluminè energija. Energijos vartojimo efektyvumo rodikliais buvo pasirinktas bendras energijos poreikis ir energijos išeigos koeficientas. Produkto sistema buvo palyginta su analogiška gamtinių dujų sistema. Neatsinaujinančios energijos išeigos koeficientas buvo naudojamas norint nustatyti, kiek kartų energijos išeiga didesnè už įeinančią neatsinaujinančią energiją. Atliktas dviejų energetinių augalų vertinimas: miskanto, kuris yra tipiškas specialiai auginamų žolinių energetinių augalų atstovas, ir gluosnio, kuris yra tipiškas specialiai medienai auginamų augalų atstovas. Ukrainoje tolesnei biokuro skiedros gamybai ir jos deginimui biokuro katiluose miskantas yra energetiškai efektyvus, jeigu gabenamas iki 300 km, o gluosnių skiedros - iki $100 \mathrm{~km}$ atstumu.

Raktažodžiai: energiniai augalai, miskantas, gluosnis, gyvavimo ciklo ịvertinimas, efektyvus energijos vartojimas, šiltnamio efektą sukeliančios dujos, bendras energijos poreikis, energijos išeigos koeficientas, bioenergijos šiluma 